\title{
Impact of Training Programme on Farmers Knowledge and Adoption about Bengal Gram Production Technology
}

\author{
A.M. Tayade ${ }^{1}$, U.R. Chinchmalatpure ${ }^{2}$ \\ Krishi Vigyan Kendra, Ghatkhed, Amravati-444 602, Maharashtra, India.
}

Received: August 2021

Accepted: January 2022

\begin{abstract}
Background: Lack of correct and inadequate knowledge leads to under or over adoption of innovation which proves fatal to the farming business. Therefore, Krishi Vigyan Kendra imparted training and demonstration programmes at Tribal area of Amravati district under TSP. Hence a study was conducted to ascertain the level of knowledge and adoption of farmers with respect to Bengal gram production technologies due to training imparted by Krishi Vigyan Kendra, Ghatkhed, Amravati. Methods: The study was carried out in three villages in tribal area of Dharni block of Amravati district, where most of the farmers were growing Bengal gram crop. To measure the impact of the training programme, the farmers were grouped as 'trainees' and 'non-trainees' and a random sample of 25 farmers from each group were drawn from KVK adopted villages of tribal area for testing their level of knowledge and extent of adoption by means of a well structured schedule.

Result: The trainees farmers had high level of knowledge and adoption than the non-trainees farmers. It was also found that calculated value of ' $t$ ' was significant at 1 per cent level of significance. It means that there is significant difference between trainees and non-trainees regarding the extent of adoption of package of practices of Bengal gram crop.
\end{abstract}

Key words: Adoption, Bengal gram, Impact, Knowledge, Training.

\section{INTRODUCTION}

Historically India is the largest producer, consumer and importer of pulses. Pulses are a good and chief source of protein for a majority of the population in India. Protein malnutrition is prevalent among men, women and children in India. Pulses contribute 11 per cent of the total intake of proteins in India (Reddy, 2010). In India, frequency of pulses consumption is much higher than any other source of protein, which indicates the importance of pulses in their daily food habits. Keeping the cheapest source of protein, it is important to increase pulses production in order to provide balanced diet among the socially and economically backward classes.

One of the main tasks of Krishi Vigyan Kendra is to provide and improve the knowledge of the trainees about the improved farm practices, because knowledge is cognitive component of individual's mind and plays an important role in covert as well as overt behaviour and individuals with a greater knowledge of technical nature of improved practices would lead to a high adoption. Lack of correct and inadequate knowledge leads to under or over adoption of innovation which proves fatal to the farming business.

Krishi Vigyan Kendra imparted training and demonstration programmes at Tribal area of Amravati district under TSP, therefore a study was conducted to ascertain the level of knowledge and adoption of farmers with respect to Bengal gram production technologies due to training imparted by Krishi Vigyan Kendra, Ghatkhed, Amravati.
Attention was, therefore focused in this study to analyze as to what extent of the training programme affected the level of knowledge and extent of adoption of recommended package of practices on Bengal gram crops on trainees. This involved the process of relating and judging the extent, the respondent was expected to ensure questions, which were posed in the test situation than the learning situation.

\section{MATERIALS AND METHODS}

The study was carried out in three villages in tribal area of Dharni block of Amravati district viz, Kota, Kara, Nanduri where most of the farmers were growing Bengal gram crop. To measure the impact of the training programme, the farmers were grouped as 'trainees' and 'non-trainees' and a random sample of 25 farmers from each group were drawn from KVK adopted villages of tribal area for testing their level of knowledge and extent of adoption by means of a well structured schedule.

\section{RESULTS AND DISCUSSION}

Knowledge level of respondents about Bengal gram crop

The data from the Table 1 shows that the trainees had high level of knowledge $(80 \%)$, followed by 20 per cent of them were found in medium level of knowledge. In case of nontrainees, 20 per cent of respondents had high level, 28 per cent had medium level and more than fifty per cent $(52 \%)$

\footnotetext{
*Corresponding author's E-mail: mahit303@gmail.com

${ }^{1}$ Krishi Vigyan Kendra, Ghatkhed, Amravati-444 602, Maharashtra, India.

${ }^{2}$ Department of Extension Education, Dr. Panjabrao Deshmukh Krishi Vidyapeeth, Akola-444 104, Maharashtra, India.
} 
had low level of knowledge. Thus it can conclude that Bengal gram grower's trainees were having high level of knowledge than the non-trainees.

\section{Practice wise adoption of improved bengal gram crop}

Table 2 shows that all the trainees were fully adopted the high yielding varieties of wheat crop, followed by timely irrigation and time of harvesting $(96 \%)$, followed by the seed rate according to scientific recommendation (88\%) Whereas, 64 per cent non-trainees adopted high yielding varieties of Bengal gram crop, 76 per cent used timely harvesting followed by the timely irrigation (44\%) and about 20 per cent who adopted the scientific seed rate.
Further, partially adopted practices by majority of trainees were control of weeds in Bengal gram crops (48\%), use of organic manure $(40 \%)$, use of chemical fertilizer as per recommendation (36\%), adopted plant protection measures $(32 \%)$ followed by used the bio-fertilizers $(28 \%)$. Whereas, incase of non-trainees partially adopted 8 per cent partially controlled weeds in Bengal gram crops, 28 per cent used the organic manure, followed by 32 per cent used the chemical fertilizer and 64 per cent used plant protection measures. Only 4 per cent of the non-trainees adopted used of bio-fertilizers.

Non-adoption of recommended practices by trainees were used of bio fertilizer $(56 \%)$, seed treatment $(48 \%)$

Table 1: Distribution of respondents according to their extent of knowledge.

\begin{tabular}{lcccc}
\hline \multirow{2}{*}{ Category } & \multicolumn{2}{c}{ Trainees $(\mathrm{n}=25)$} & \multicolumn{2}{c}{ Non trainees $(\mathrm{n}=25)$} \\
\cline { 2 - 5 } & Frequency & Percentage & Frequency & Percentage \\
\hline Low (Up to 12) & 00 & 00.00 & 13 & 52.00 \\
Medium (13 to 15) & 05 & 20.00 & 07 & 28.00 \\
High (Above 15) & 20 & 80.00 & 05 & 25 \\
& 25 & 100.00 & 25 & 100.00 \\
\hline
\end{tabular}

Table 2: Distribution of respondents of according to the practice wise adoption.

\begin{tabular}{|c|c|c|c|c|c|c|}
\hline \multirow{3}{*}{ Statement } & \multicolumn{6}{|c|}{ Extent of adoption } \\
\hline & \multicolumn{3}{|c|}{ Trainees } & \multicolumn{3}{|c|}{ Non trainees } \\
\hline & $\begin{array}{l}\text { Fully } \\
\text { adopted }\end{array}$ & $\begin{array}{l}\text { Partially } \\
\text { adopted }\end{array}$ & $\begin{array}{l}\text { Non } \\
\text { adopted }\end{array}$ & $\begin{array}{l}\text { Fully } \\
\text { adopted }\end{array}$ & $\begin{array}{l}\text { Partially } \\
\text { adopted }\end{array}$ & $\begin{array}{l}\text { Non } \\
\text { adopted }\end{array}$ \\
\hline $\begin{array}{l}\text { Did you grow high yielding varieties of } \\
\text { Bengal gram crop }\end{array}$ & $25(100.00)$ & $00(00.00)$ & $00(00.00)$ & $16(64.00)$ & $09(36.00)$ & $00(00.00)$ \\
\hline Did you follow seed treatment? & $12(48.00)$ & $01(04.00)$ & $12(48.00)$ & $01(04.00)$ & $00(00.00)$ & $24(96.00)$ \\
\hline $\begin{array}{l}\text { Do you follow the seed rate according to } \\
\text { scientific recommendation? }\end{array}$ & $22(88.00)$ & $03(12.00)$ & $00(00.00)$ & $05(20.00)$ & $04(16.00)$ & $16(64.00)$ \\
\hline Do you follow the right time of sowing? & $20(80.00)$ & $05(20.00)$ & $00(00.00)$ & $12(48.00)$ & $09(36.00)$ & $04(16.00)$ \\
\hline Do you follow the sowing depth of Bengal gram? & $19(76.00)$ & $06(24.00)$ & $00(00.00)$ & $06(24.00)$ & $11(44.00)$ & $08(32.00)$ \\
\hline Have you used the bio-fertilizers & $04(16.00)$ & $07(28.00)$ & $14(56.00)$ & $00(00.00)$ & $01(04.00)$ & $24(96.00)$ \\
\hline Have you used the organic manure? & $09(36.00)$ & $10(40.00)$ & $06(24.00)$ & $01(04.00)$ & $07(28.00)$ & $17(68.00)$ \\
\hline $\begin{array}{l}\text { Did you use the chemical fertilizer as per } \\
\text { recommendation? N P K }\end{array}$ & $04(16.00)$ & $09(36.00)$ & $12(48.00)$ & $00(00.00)$ & $08(32.00)$ & $17(68.00)$ \\
\hline Did you follow the time of irrigation? & $24(96.00)$ & $01(00)$ & $00(00)$ & $11(44)$ & $09(36.00)$ & $05(20.00)$ \\
\hline Did you control weeds in Bengal gram crops? & $13(52.00)$ & $12(48)$ & $00(00)$ & $05(20$ & $02(08.00)$ & $18(72.00)$ \\
\hline $\begin{array}{l}\text { Did you follow plant protection measures for } \\
\text { control of pest and diseases? }\end{array}$ & $14(56.00)$ & $08(32.00)$ & $3(12.00)$ & $01(04.00)$ & $16(64.00)$ & $08(32.00)$ \\
\hline Did you follow up the time of harvesting? & $24(96.00)$ & $01(04.00)$ & $00(00.00)$ & $19(76.00)$ & $06(24.00)$ & $00(00.00)$ \\
\hline
\end{tabular}

Table 3: Distribution of respondents according to their extent of adoption.

\begin{tabular}{lcccc}
\hline \multirow{2}{*}{ Category } & \multicolumn{2}{c}{ Trainees } & \multicolumn{2}{c}{ Non trainees } \\
\cline { 2 - 5 } & Frequency & Percentage & Frequency & Percentage \\
\hline Low (Up to 10) & 00 & 00.00 & 08 & 32.00 \\
Medium (11 to 14) & 04 & 16.00 & 16 & 64.00 \\
High (15 and above) & 21 & 84.00 & 01 & 04.00 \\
& 25 & 100.00 & 25 & 100.00 \\
\hline
\end{tabular}

' $\mathrm{x}^{2}$ cal.= 33.38. 
followed by use of organic manure (24\%), whereas in case of non-trainees, non-adoption of recommended technologies were 96 per cent used of bio fertilizer and seed treatment, followed by used of organic manure (64\%).

Adoption level of respondents about Bengal gram crop

Data (Table 3) shows that most of the trainees (84\%) have had higher level of adoption followed by medium level (16\%), whereas, most of the non-trainees have had medium level of adoption (64\%) followed by low level of adoption (32\%). It shows that trainees were having higher level of adoption of recommended package of practices than the non-trainees.

It was also found that calculated value of $\mathrm{X} 2$ was 33.38 and calculated value of ' $t$ ' was 11.28 both were significant at $1 \%$ level of significance. It means that there is significant difference between trainees and non-trainees regarding the extent of adoption of package of practices of Bengal gram crop. It shows that trainees had higher level of adoption of recommended package of practices as also higher mean scores than the non-trainees. The above findings are in line with the findings reported by Saxena and Singh (2000) Ahirwar (2011), Jatav (2011) and Samantaray (2016).

\section{CONCLUSION}

It can be concluded that KVK is able to bring significant changes in the level of knowledge and adoption of Bengal gram production technologies among trainees in tribal area. Training and guidance given to trainees have played prime role in influencing technological changes, besides management orientation. Therefore, there is need to give thrust of these factors with suitable changes in training curriculum and time by the scientists for fulfilling the objective of KVK training programmes.

\section{REFERENCES}

Ahirwar, R. (2011). A study of training needs of chickpea growers in Khurai block of Sagar district, (M.P.). M.Sc. (Ag.) Thesis, Jawaharlal Nehru Krishi Vishwa Vidyalaya, Jabalpur, M.P. (India).

Jatav, D.K. (2011). Impact of K.V.K. training programmes on mustard production technology among participating and nonparticipating farmers in Vijaypur block of Sheopur district, (M.P.) M.Sc. (Ag.) Thesis, Jawaharlal Nehru Krishi Vishwa Vidyalaya, Jabalpur, M.P. (India).

Samantaray, S.K. (2016). Impact of training programmes on knowledge and adoption of organic farming practices. Global Journal of Science Frontier Research: Agriculture and Veterinary. 16(5): 35-38.

Saxena, K.K. and Singh, R.L. (2000). Adoption of organic farming practices by farmers of Malwa Region. Mah. J. Ext. Edu. 21: 53-54. 